\title{
Infectious mononucleosis mimicking lymphoma: distinguishing morphological and immunophenotypic features
}

\author{
Abner Louissaint Jr, Judith A Ferry, Chad P Soupir, Robert P Hasserjian, Nancy L Harris \\ and Lawrence R Zukerberg
}

The James Homer Wright Pathology Laboratories, Massachusetts General Hospital, Boston, MA, USA

\begin{abstract}
The diagnosis of infectious mononucleosis (acute Epstein-Barr virus (EBV) infection) is usually made on the basis of clinical and laboratory findings. However, an atypical clinical presentation occasionally results in a lymph node or tonsillar biopsy. The morphological features of EBV-infected lymphoid tissue can easily mimic lymphoma. Furthermore, the immunophenotype of the immunoblasts has not been well characterized. To assess the morphological spectrum of acute EBV infection and the utility of immunohistochemistry in diagnosing difficult cases that resemble lymphoma, we reviewed 18 cases of acute EBV infection submitted in consultation to our institution with an initial diagnosis of/or suspicion for lymphoma. Patients included nine male and nine female individuals with a median age of 18 years (range 9-69). Biopsies were obtained from lymph nodes $(3 / 18)$ or Waldeyer's ring (15/18). Infectious mononucleosis was confirmed by monospot or serological assays in $72 \%$ of cases (13/18). All cases featured architectural distortion by a polymorphous infiltrate with an immunoblastic proliferation, sometimes forming sheets. Reed-Sternberg-like cells were present in $8 / 18(44 \%)$ of the cases. Infiltrates were often accompanied by necrosis (10/18) and mucosal ulceration (6/15). The majority of immunoblasts in all cases were CD20 + B cells with a post-germinal center immunophenotype (strongly positive for MUM1/IRF4 (18/18), CD10 - (18/18 negative) and BCL-6- (16/18 negative; $2 / 18$ faint BCL- 6 expression in $<10 \%$ of immunoblasts)). Immunoblasts showed variable weak expression of BCL-2 and polyclonal expression of $\kappa$ and $\lambda$ immunoglobulin light chains in $81 \%$ cases. ReedSternberg-like cells in 8/8 cases were CD30+, CD15-, BOB.1+ and OCT-2 + . In conclusion, an atypical lymphoid infiltrate with numerous MUM1 +, CD10-, BCL-6- immunoblasts should raise the suspicion of a reactive process, such as infectious mononucleosis, and warrants additional consideration before a diagnosis of lymphoma is made.
\end{abstract}

Modern Pathology (2012) 25, 1149-1159; doi:10.1038/modpathol.2012.70; published online 25 May 2012

Keywords: Epstein-Barr virus; infectious mononucleosis; lymphoma

Epstein-Barr virus (EBV) infects more than $90 \%$ of the human population and persists in most individuals as a lifelong, asymptomatic infection of $\mathrm{B}$ lymphocytes. Acute infectious mononucleosis, most specifically characterized by the triad of tonsillitis/ pharyngitis, cervical lymphadenopathy and fever, is the most common acute clinical manifestation of primary EBV infection. ${ }^{1}$ Although primary EBV infection may occur at any age, the incidence of

Correspondence: Dr A Louissaint, MD, PhD, The James Homer Wright Pathology Laboratories, Massachusetts General Hospital, 55 Fruit Street, Warren 2, Boston, MA 02114, USA.

E-mail: alouissaint@partners.org

Received 25 October 2011; revised 22 December 2011; accepted 23 December 2011; published online 25 May 2012 acute infectious mononucleosis begins to rise in adolescence and declines through adulthood. ${ }^{2}$ Primary EBV infections in young children are common and frequently subclinical. However, a small subset of young infants and children with primary EBV infection will also present with infectious mononucleosis. ${ }^{3}$ For most cases, the diagnosis of acute infectious mononucleosis is made on the basis of clinical presentation and laboratory findings, including the presence of lymphocytosis with atypical lymphocytes and confirmatory serology/monospot test. ${ }^{4}$ However, acute EBV infection can occasionally be associated with large or asymmetric lymph nodes or tonsillar masses (frequently out of proportion to pharyngitis/tonsillitis) that may be biopsied to rule out lymphoma. Unfortunately, these biopsies can 
lead to a misdiagnosis of lymphoma, as involvement of lymphoid tissue by acute EBV infection can resemble both Hodgkin lymphoma and non-Hodgkin lymphoma. ${ }^{5-20}$ This relatively common pitfall can result in inappropriate treatment. Morphological features mimicking non-Hodgkin lymphoma include extensive proliferation of immunoblasts, often in sheets, with marked cytological atypia. ${ }^{13,14,17,20}$ Similarly, Hodgkin lymphoma can be simulated, in part, by the presence of atypical Reed-Sternberg-like cells. $^{9-11,20,21}$

Although the morphological features associated with acute EBV infection of lymphoid tissue have been described, the immunophenotypic features have not been fully characterized. In this report, we review 18 cases of acute EBV infection in which the involved lymph node or Waldeyer's ring tissue was biopsied or sampled. In most cases, the biopsy was prompted by a large or asymmetric mass and/or an unusual clinical presentation for infectious mononucleosis (ie older patient, ${ }^{22}$ the presence of symptomatic lymphadenopathy/airway obstruction $^{12}$ ). The majority of cases were submitted to our department by pathologists who were concerned for lymphoma on the basis of a worrisome histological appearance. In this study, we describe the morphological and immunophenotypic features that are shared by these cases of infectious mononucleosis mimicking lymphoma and may be helpful in their recognition.

\section{Materials and methods}

In all, 18 cases of acute EBV infection involving cervical lymph nodes or Waldeyer's ring tissue were identified from the consultation files of two of the authors. The cases were initially reviewed between the years of 2001 and 2009. The original hematoxylin- and eosin-stained and immunohistochemically stained slides were retrieved and reviewed in all cases. A panel including in-situ hybridization and immunohistochemical stains was performed and evaluated in all cases on formalin-fixed, paraffin-embedded sections. Immunohistochemical stains and in-situ hybridizations performed most recently were performed using the Ventana Benchmark Autostainer (Ventana Medical Systems, Tucson, AZ, USA) using the Ventana 3, 3'-diaminobenzidine tetrahydrochloride kit according to the manufacturer's instructions. Primary antibodies included antibodies to CD3, CD4, CD8, CD20, MUM1/IRF4, BCL-2, BCL-6, OCT-2, BOB.1, CD10, CD30, CD15, CD138, $\lambda$ and $\kappa$ immunoglobulin light chains, and IgD, IgM, IgG and IgA heavy chains (Table 1). For each case, the immunophenotype of the cells comprising the immunoblast population and the background infiltrate was determined based on this panel of markers. To assess the relative expression of particular antigens by immunoblasts, the positivity of each immunostain was scored as follows: 0 (absent staining in immuno-
Table 1 Antibodies and probes used for immunophenotypic analysis

\begin{tabular}{lll}
\hline Antibody & Source & Dilution \\
\hline CD20 & Ventana & Prediluted \\
CD10 & Ventana & Prediluted \\
BCL-2 & Ventana & Prediluted \\
MUM1/IRF4 & Dako & $1: 20$ \\
BCL-6 & Novocastra & $1: 100$ \\
CD3 & Ventana & Prediluted \\
CD4 & Novocastra & NEAT (undiluted) \\
CD8 & Ventana & Prediluted \\
CD30 & Ventana & Prediluted \\
CD15 & Ventana & Prediluted \\
OCT-2 & Santa Cruz & $1: 500$ \\
BOB.1 & Santa Cruz & $1: 300$ \\
& & \\
Immunoglobulin heavy and light chains & \\
$\kappa$ & Dako & $1: 2000$ \\
$\lambda$ & Dako & $1: 1400$ \\
$\mu$ & Dako & $1: 3500$ \\
$\gamma$ & Dako & $1: 3000$ \\
$\alpha$ & Dako & $1: 1000$ \\
$\delta$ & TFS & NEAT \\
In-situ probe & & \\
$\kappa, \lambda$ (in-situ hybridization) & Ventana & Prediluted \\
EBV-EBER (in situ & Ventana & Prediluted \\
hybridization) & & \\
& & \\
\hline
\end{tabular}

Sources: Ventana, Tucson, AZ, USA; Dako Corporation, Carpinteria, CA, USA; Novocastra, Burlingame, CA, USA; Santa Cruz, Santa Cruz, CA, USA; Thermo Fisher Scientific (TFS), Fremont, CA, USA.

blasts $), 1+(<10 \%$ immunoblasts positive $), 2+$ $(10-80 \%$ immunoblasts positive) and $3+(>80 \%$ immunoblasts positive).

Clinical follow-up information was obtained from pathologists and clinicians at the referring institution in all cases. This project was reviewed and approved by the Partners Institutional Review Board.

\section{Results}

\section{Clinical Features}

The 18 patients ranged from 9 to 69 years of age (mean 24 years; median 18 years), with $3 / 18$ (17\%) older than 25 years, and included nine female and nine male patients. Patients presented with neck and tonsillar pain (7/18), pharyngitis (2/18), tonsillitis (4/18) and/or peritonsillar abscess (4/18), but were occasionally asymptomatic (4/18). None of the patients had a history of immunodeficiency or immunosuppression. In all 18 patients, the mass and/or lymphadenopathy raised a concern of lymphoma and resulted in a biopsy. Eight $(8 / 18 ; 44 \%)$ of the cases had at least one particularly unusual or worrisome clinical feature, such as age $>25$ years (3/18) and/or airway obstruction (4/18) (Table 2). Biopsies were taken from cervical lymph nodes (3/18, $17 \%)$ or tonsil/adenoid/associated Waldeyer ring tissue $(15 / 18,83 \%)$. All cases were received in 


\begin{tabular}{|c|c|c|c|c|c|c|c|c|}
\hline No. & Age & Sex & Clinical presentation & Extent of $L A D$ & Specimen & Initial diagnosis & Serology & $\begin{array}{c}F / U \\
\text { (months) }\end{array}$ \\
\hline 1 & 9 & M & Asymptomatic & LN (cervical) & LN (cervical) & $\begin{array}{l}\text { Lymphoma (DLBCL } \\
\text { vs Hodgkin) }\end{array}$ & ND & 54 \\
\hline 2 & 19 & M & Right neck mass & LN (cervical) & LN (cervical) & (?) lymphoma & $\begin{array}{l}\text { Positive serology: VCA IgM (+); } \\
\text { VCA IgG }(+) ; \text { EA IgG }(+) \text {; } \\
\text { EBNA IgG }(-)\end{array}$ & 19 \\
\hline 3 & 69 & M & Asymptomatic lymphadenopathy & LN (cervical, axillary) & LN (cervical) & (?) lymphoma & $\begin{array}{l}\text { Positive serology: VCA IgM (+); } \\
\text { VCA IgG (-); }\end{array}$ & 101 \\
\hline 4 & 11 & $\mathrm{~F}$ & Nasopharyngeal mass & $\begin{array}{l}\text { Adenoids, } \\
\text { terminal ileum }\end{array}$ & Adenoids & (?) Lymphoma & Positive monospot & 17 \\
\hline 5 & 17 & $\mathrm{~F}$ & Peritonsillar abscess & Tonsils (b) & Tonsils (b) & (?) Hodgkin lymphoma & ND & 53 \\
\hline 6 & 17 & $\mathrm{~F}$ & Asymptomatic & Tonsils (b) & Tonsils (b) & (?) Hodgkin lymphoma & ND & 27 \\
\hline 7 & 17 & $\mathrm{M}$ & Airway obstruction & Tonsils (b) & Tonsils (b) & (?) Lymphoma & Positive monospot & 92 \\
\hline 8 & 17 & $\mathrm{M}$ & $\begin{array}{l}\text { Sore throat, fatigue, malaise, } \\
\text { peritonsillar abscess, splenomegaly }\end{array}$ & $\begin{array}{l}\text { Tonsils (b), } \\
\text { LN (mediastinal, } \\
\text { cervical, axillary) }\end{array}$ & Tonsils (b) & DLBCL & Positive monospot & 41 \\
\hline 9 & 18 & $\mathrm{~F}$ & $\begin{array}{l}\text { Airway compromise, pharyngitis, } \\
\text { cervical lymphadenopathy }\end{array}$ & $\begin{array}{l}\text { Tonsils (b) and adenoids, } \\
\text { LN (cervical) }\end{array}$ & Tonsils (b) & (?) Lymphoma & Positive monospot & 29 \\
\hline 10 & 18 & $\mathrm{~F}$ & Chronic tonsillitis & Tonsils (b) & Tonsils (b) & $\begin{array}{l}\text { Atypical lymphoid } \\
\text { infiltrate }\end{array}$ & Positive monospot & 55 \\
\hline 11 & 18 & $\mathrm{~F}$ & $\begin{array}{l}\text { Sinusitis, tonsillitis, airway } \\
\text { compromise }\end{array}$ & Tonsils (b) & $\begin{array}{l}\text { Tonsils (b) } \\
\text { adenoids }\end{array}$ & Hodgkin lymphoma & ND & 13 \\
\hline 12 & 19 & $\mathrm{~F}$ & Neck and tonsillar pain & $\begin{array}{l}\text { Tonsils (b) and adenoids, } \\
\text { LN (cervical) }\end{array}$ & $\begin{array}{l}\text { Tonsils (b) } \\
\text { adenoids }\end{array}$ & (?) Hodgkin lymphoma & Positive monospot & 70 \\
\hline 13 & 20 & $\mathrm{M}$ & Severely hypertrophic tonsils & Tonsils (b) & Tonsils (l) & Atypical lymphoid infiltrate & Positive monospot & 64 \\
\hline 14 & 21 & M & $\begin{array}{l}\text { Acute pharyngitis and peritonsillar } \\
\text { abscess }\end{array}$ & Tonsils (l) & Tonsils (l) & (?) Lymphoma & Positive monospot & 29 \\
\hline 15 & 22 & $\mathrm{~F}$ & $\begin{array}{l}\text { Pharyngeal obstruction, bilateral neck } \\
\text { and mediastinal lymphadenopathy, } \\
\text { enlarged tonsils }\end{array}$ & $\begin{array}{l}\text { Tonsils (b); LN (cervical, } \\
\text { mediastinal) }\end{array}$ & $\begin{array}{l}\text { Tonsil, } \\
\text { biopsy (l) }\end{array}$ & $\begin{array}{l}\text { Plasmablastic } \\
\text { lymphoma }\end{array}$ & Positive monospot & 39 \\
\hline 16 & 23 & M & $\begin{array}{l}\text { Acute tonsillar pharyngitis and } \\
\text { peritonsillar abscess }\end{array}$ & Tonsils (b) & Tonsil (b) & (?) Lymphoma & ND & 51 \\
\hline 17 & 39 & M & Neck and tonsillar pain & Tonsils (b) & Tonsils (b) & DLBCL & $\begin{array}{l}\text { Positive serology: VCA IgM (+); } \\
\text { VCA IgG }(+) \text {; EA IgG }(+) \text {; } \\
\text { EBNA IgG }(-)\end{array}$ & 67 \\
\hline 18 & 60 & $\mathrm{~F}$ & $\begin{array}{l}\text { Asymptomatic asymmetric } \\
\text { enlargement } \\
\text { of right tonsil }\end{array}$ & Tonsil (r) & Tonsil, biopsy & (?) Lymphoma & $\begin{array}{l}\text { Positive serology: VCA IgM (+); } \\
\text { VCA IgG (-); }\end{array}$ & 56 \\
\hline
\end{tabular}

EA, early antigen; EBNA, Epstein-Barr virus nuclear antigen; EBV, Epstein-Barr virus; VCA, viral capsid antigen; DLBCL, diffuse large B-cell lymphoma; LN, lymph node; R, right; L, left; B, bilateral; ND, not done; M, male; F, female. 
consultation with a question of lymphoma (Table 2). A diagnosis of lymphoma (Hodgkin lymphoma, diffuse large B-cell lymphoma, plasmablastic lymphoma) had already been made in 5 of 18 cases $(28 \%)$ before submission to our department. In the other cases, the diagnosis of lymphoma had been considered: lymphoma (8), Hodgkin lymphoma (3) and atypical lymphoproliferative (2). Testing of the patient for acute EBV infection was suggested at the time of consultation for confirmation of primary systemic infectious mononucleosis. In 13/18 cases, evidence of acute EBV infection was confirmed by EBV serology or positive monospot (Table 2).

\section{Histopathological Features}

In all cases, there was expansion of the interfollicular areas by a polymorphous infiltrate, resulting in distortion, but not obliteration, of the normal tissue architecture (Figures 1a and b). The interfollicular infiltrate characteristically consisted of large round to irregular cells with vesicular nuclei, prominent nucleoli and scant basophilic cytoplasm, consistent with immunoblasts, in a background of small- and intermediate-sized lymphoid cells, plasma cells, histiocytes and admixed high endothelial venules (Figure 1b). Immunoblasts were frequently present in aggregates or occasionally sheets and were mitotically active (Figures 1c and d and Table 3). Pleomorphic Reed-Sternberg-like cells were present in a subset of cases (8/18) (Figure 1c, inset). More than half of the cases also contained areas of geographic necrosis (11/18), usually within expanded interfollicular areas (Figure 1f and Table 3). Despite these worrisome features (distortion of the architecture, aggregates and sheets of large cells, Reed-Sternberg-like cells and necrosis), significant areas of normal lymph node or tonsillar architecture were retained in all cases. Areas of normal lymphoid architecture often merged with more abnormal areas. In Waldeyer ring tissue, crypts were preserved, but focally associated with ulceration of the tonsillar mucosa in 11/15 cases (73\%) (Figure 1e). Peritonsillar abscesses were present in 5/15 cases (33\%). In lymph node tissue, reactive follicles as well as subcapsular, cortical and medullary sinuses were generally preserved; follicular hyperplasia was present in 4/18 cases (Table 3).

\section{Immunohistochemistry and In-Situ Hybridization}

In all cases, in-situ hybridization for EBV-encoded RNA revealed a heterogeneous population of small to large EBV + cells, predominantly within the interfollicular infiltrate, many of which were immunoblasts (Figure 2a). Rare small EBV + lymphoid cells were present in germinal centers, and occasional scattered EBV + cells were identified within follicle mantles, but EBV + immunoblasts were not found in germinal centers (Figure 2b). The majority of immunoblasts were CD20 + B cells, although occasional $\mathrm{CD} 3+$ immunoblast-like cells were focally present as well in some cases (Figures 3a and b). In each case, the majority of immunoblasts (>50\%) were positive for MUM1/IRF4 (18/18) and negative for germinal center markers CD10 (negative in 18/18 cases) and BCL-6 (negative in 16/18 cases, $<10 \%$ BCL-6 faintly positive immunoblasts in 2/18 cases), consistent with a post-germinal center phenotype (Figures 3c and e and Table 4). Immunoblasts were weakly positive for BCL-2 9/17 cases (Table 4 and Figure 3f). In all cases examined, the majority of immunoblasts expressed OCT-2, BOB.1 and CD30 (Figures $3 \mathrm{~g}$ and $\mathrm{i}$ ), but were negative for CD15 (Table 4). Reed-Sternberg-like cells had an identical immunophenotype to the immunoblasts in all cases in which they were identified (8/8 cases). In-situ hybridization for $\kappa$ and $\lambda$ light chains showed numerous plasma cells with polyclonal expression; expression of light chains in immunoblasts was often difficult to define using this technique (Figures 4a and b). However, using immunohistochemical stains for $\kappa$ and $\lambda$ light chains, there was polytypic expression in immunoblasts in 13/16 cases (Figures 4c and d and Table 4). Immunoblasts were found to express predominantly a mixture of IgG and IgM heavy chains.

Immunoblasts were admixed within a polymorphous infiltrate, predominantly composed of small CD3 + T cells with admixed small CD20 + B cells and CD138 + plasma cells. The number of CD3 $+\mathrm{T}$ cells greatly outnumbered the CD20 + B cells in the majority of cases. Moreover, immunohistochemical stains for CD4 and CD8 revealed a significantly decreased or inverted CD4:CD8 ratio in most cases evaluated $(12 / 14)$. Plasma cells were polyclonal by in-situ hybridization (8/8 cases) and/or immunohistochemistry for $\kappa$ and $\lambda$ light chains (10/10 cases) (Figures 4a and b). Plasma cells expressed IgG, IgM and IgA heavy chains, with rare IgD + plasma cells.

\section{Clinical Follow-up}

Monospot testing (nine cases) or serological testing (four cases) was performed and the results were available. Monospot testing was found to be positive in 9/9 cases, and EBV-specific serologic tests were consistent with recent infection in 4/4 cases (Table 2). In all patients, lymphadenopathy and symptoms subsided with treatment. There was no evidence of lymphoma or recurrence or progression of disease, with follow-up ranging from 13 to 102 months (mean 49; median 52 months).

\section{Discussion}

We report 18 cases of patients with lymphadenopathy or enlargement of Waldeyer's ring tissue associated with acute EBV infection, in which a biopsy was performed to evaluate for the possibility 

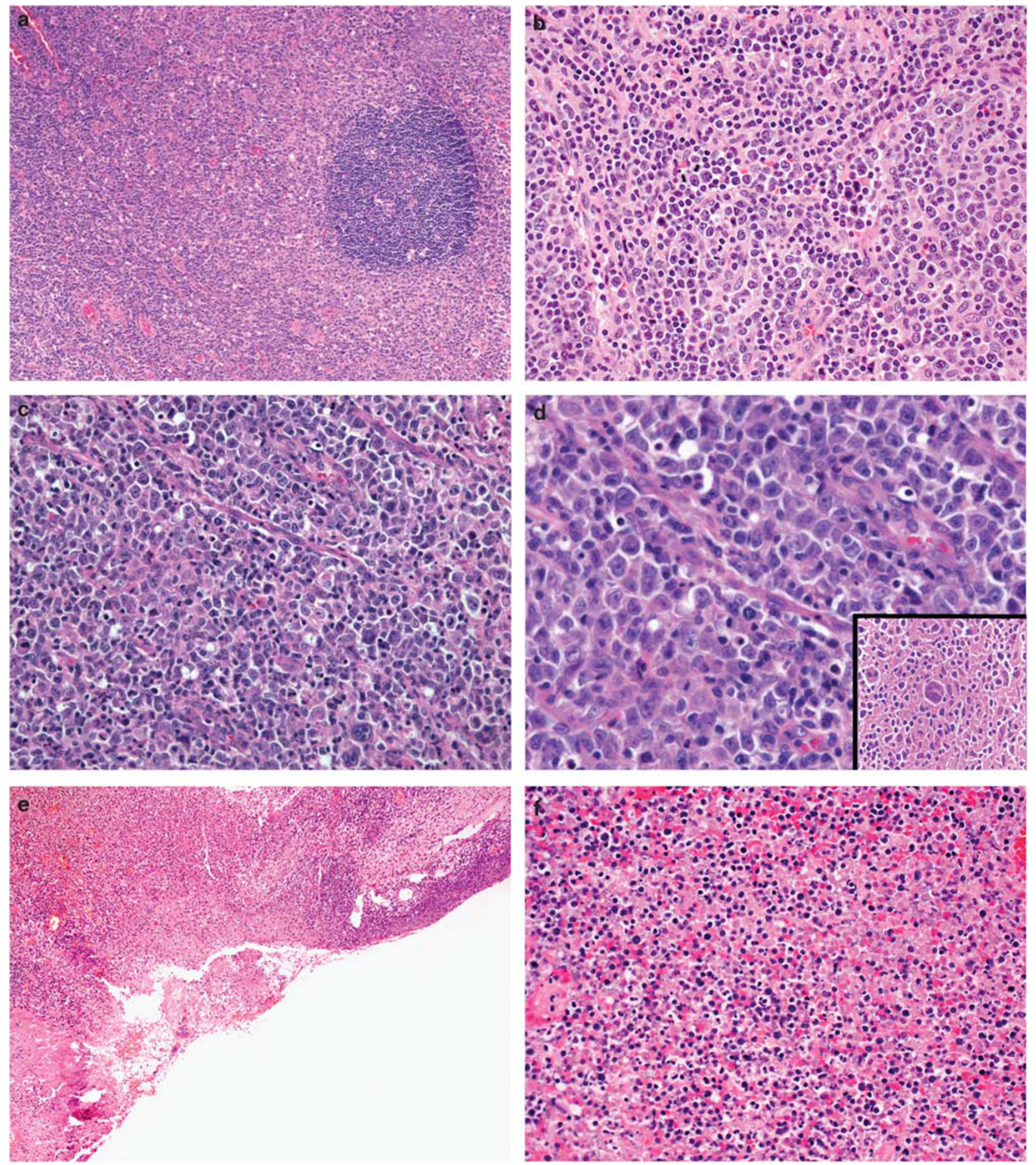

Figure 1 Characteristic morphological features of infectious mononucleosis cases. All cases showed interfollicular expansion with at least focal distortion of normal tissue architecture (a). The infiltrate was usually polymorphous, consisting of scattered immunoblasts in a background of numerous small mature lymphocytes, plasma cells and histiocytes (b). In areas, the immunoblastic proliferation was extensive with marked cytological atypia, numerous mitoses and focally forming sheets (c, d). Reed-Sternberg-like cells were present in 9/18 cases (d, inset). A significant number of tonsillar specimens were associated with ulceration of the tonsillar mucosa (e). More than half of the cases also featured focal geographic necrosis (11/18), usually within expanded interfollicular areas (f).

of malignancy. All cases were considered worrisome for lymphoma by pathologists, on the basis of morphological features, including the presence of a florid immunoblastic proliferation, distortion of the underlying nodal or tonsillar architecture, the presence of necrosis and/or the presence of Reed- 
Sternberg-like or bizarre large cells within the infiltrate. The cases shared a number of morphological and immunophenotypic features that proved helpful in the distinction of acute EBV infection from lymphoma.

The most commonly considered diagnosis by referring pathologists in the initial evaluation of the current infectious mononucleosis cases was diffuse large B-cell lymphoma. In fact, $20 \%$ of the cases in this series were submitted having had already been incorrectly been diagnosed as diffuse large B-cell lymphoma. While the distinction between lymphoma and infectious mononucleosis is often not difficult, the overcalling of florid cases of infectious mononucleosis continues to be a diagnostic pitfall for the practicing pathologist in many cases. ${ }^{14,20}$ Diffuse large B-cell lymphoma is the most common type of non-Hodgkin lymphoma $(31 \%$ of cases). ${ }^{23}$ The median age is 64 years, but patients of any age can be affected. ${ }^{24}$ Patients typically present with rapidly enlarging lymph nodes or tumor masses in extranodal sites. ${ }^{24}$ Waldeyer's ring is a

Table 3 Summary of morphological features

\begin{tabular}{lcc}
\hline & $\begin{array}{c}\text { Lymph node } \\
(\mathrm{n}=3)\end{array}$ & $\begin{array}{c}\text { Waldeyer's ring } \\
(\mathrm{n}=15)\end{array}$ \\
\hline Paracortical expansion & $3 / 3$ & $15 / 15$ \\
Architectural distortion & $3 / 3$ & $15 / 15$ \\
Polymorphous infiltrate & $3 / 3$ & $15 / 15$ \\
Increased immunoblasts & $3 / 3$ & $15 / 15$ \\
Preserved areas & $3 / 3$ & $15 / 15$ \\
Reed-Sternberg-like cells & $1 / 3$ & $8 / 15$ \\
Follicular hyperplasia & $0 / 3$ & $4 / 15$ \\
Abscess & $0 / 3$ & $5 / 15$ \\
Ulcerated mucosa & N/A & $11 / 15$ \\
Necrosis & $2 / 3$ & $9 / 15$ \\
\hline
\end{tabular}

common extranodal site. ${ }^{24}$ Diffuse large B-cell lymphoma characteristically shows a diffuse pattern of infiltration, commonly resulting in total architectural effacement of lymph or tonsillar architecture. However, in some cases, involvement by diffuse large B-cell lymphoma may show partial architectural effacement, and partial nodal involvement may occasionally be interfollicular, sometimes making distinction from infectious mononucleosis particularly difficult. ${ }^{25}$

In all of the cases reviewed, certain morphological features raised the possibility of a reactive process, even in the presence of the worrisome features described previously. One consistent morphological feature in all cases was the predominantly polymorphous nature of the infiltrate. Even when large aggregates or sheets of immunoblasts were present, the majority of the infiltrate was almost always composed of reactive appearing small lymphoid cells, plasma cells, histiocytes and high endothelial venules. Moreover, despite the architectural distortion resulting from the frequently extensive interfollicular expansion, sinuses and follicles frequently remained intact, although occasionally obscured. In addition, significant areas of preserved lymph node or tonsillar architecture were identified in all cases reviewed.

We reviewed a panel of markers (including MUM1/IRF4, CD10, BCL-6 and BCL-2) that was found to be particularly helpful in distinguishing the large activated cells of infectious mononucleosis from large neoplastic cells of diffuse large B-cell lymphoma. A majority of stains in the panel were applied at the time of consultation, with any remaining stains performed at the time of re-review for the purposes of this study. In each case, we found that the immunoblasts consistently had a non-germinal center phenotype: MUM1 +, BCL-6-
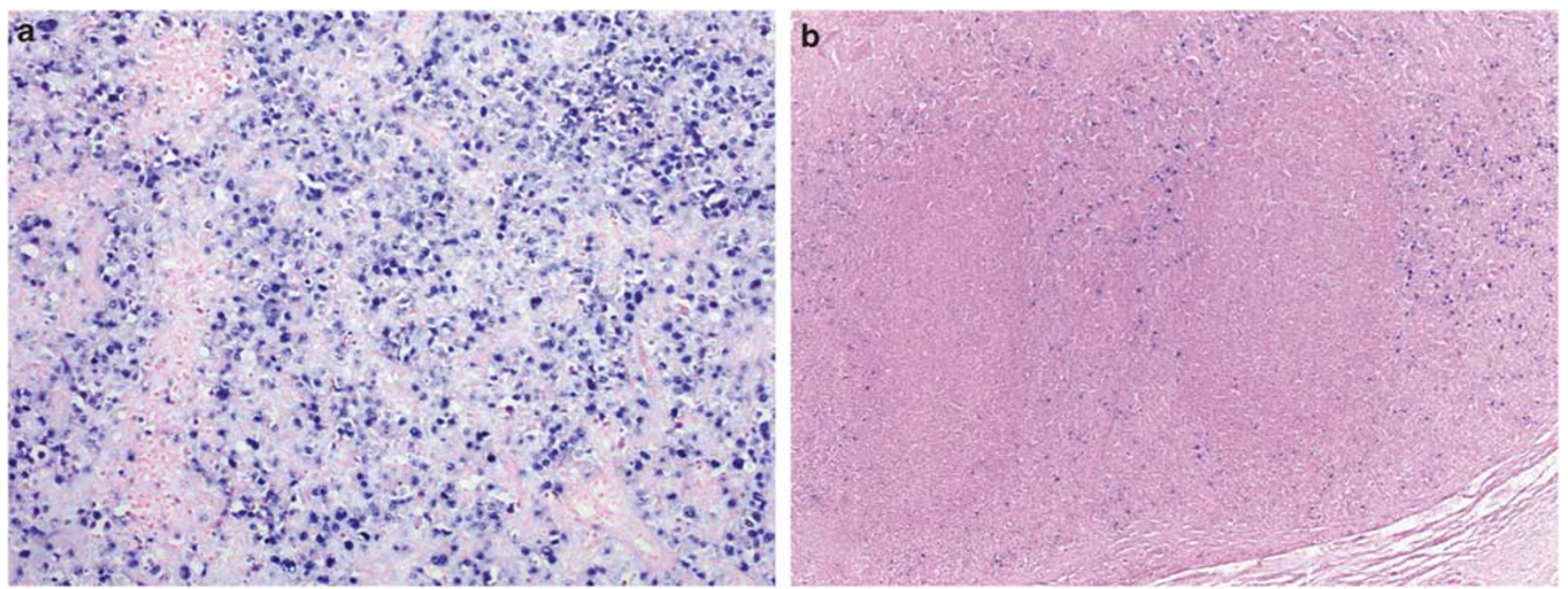

Figure 2 Detection of Epstein-Barr virus encoded RNA by in-situ hybridization. EBV-encoded RNA + cells including immunoblasts and small- to medium-sized cells were present in all cases (a). Interestingly, EBV-encoded RNA + immunoblasts were predominantly present within the interfollicular infiltrate, with scattered EBV-encoded RNA + cells within follicle mantles and only rare small EBV-encoded RNA + cells within germinal centers. EBV-encoded RNA + immunoblasts were generally restricted from germinal centers (b). 

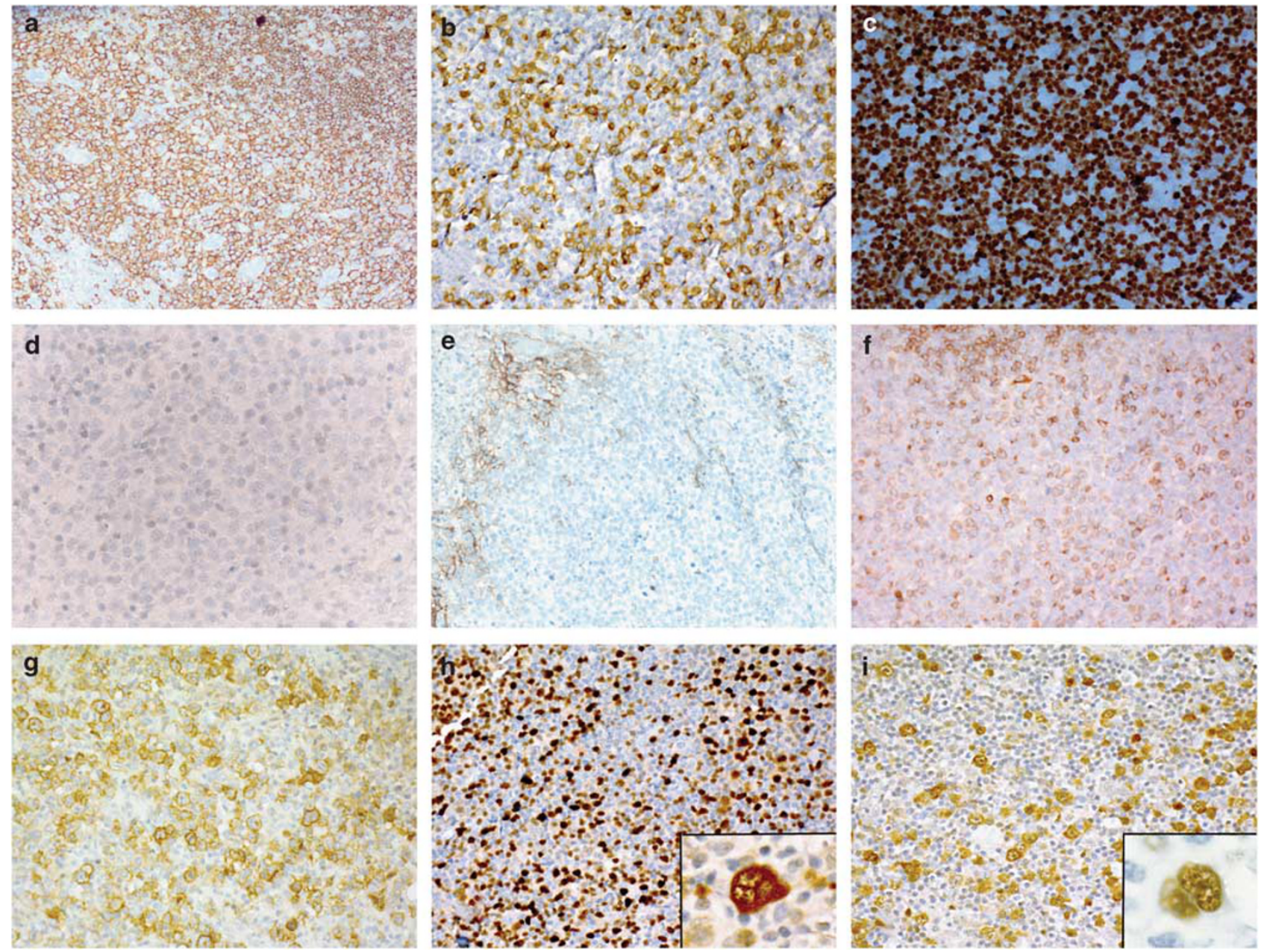

Figure 3 Characteristic immunophenotype of immunoblasts. Immunoblasts were characteristically CD20 + B cells (a); while most CD3 + cells corresponded to small mature lymphocytes, there were occasional larger CD3 + cells with immunoblast-like morphology (b). Immunoblasts were positive for MUM1(c), negative for BCL-6 (d) and CD10 (e), and showed focal dim staining for BCL-2 (f). Immunoblasts were positive for CD30 (g), negative for CD15 (not shown) and retained expression of both BOB.1 (h) and OCT-2 (i). This was also true for Reed-Sternberg-like cells (insets, $\mathbf{h}$ and i), which helped distinguish them from neoplastic Reed-Sternberg cells.

and CD10-. The immunoblasts were also generally positive for CD30 and EBV-encoded RNA, and frequently showed polyclonal expression of $\kappa$ and $\lambda$ light chains. The combination of EBV-encoded RNA +, CD30 + large activated cells with nongerminal center phenotype (MUM1/IRF4 +, CD10-, BCL-6-), in a polymorphous background with inverted CD4:CD8, is relatively unusual in diffuse large B-cell lymphoma. Therefore, in an adolescent or young adult, an atypical lymphoid infiltrate with numerous MUM1 +, CD10-, BCL-6- immunoblasts should raise the suspicion of a reactive process, such as infectious mononucleosis.

However, it is important to note that the nongerminal center phenotype can be seen in approximately $25 \%$ of diffuse large B-cell lymphoma cases, ${ }^{26}$ including a minority of EBV + CD30 + diffuse large B-cell lymphoma associated with acquired immunodeficiency, including HIV infection, organ transplantation and methotrexate treat- ment in rheumatoid arthritis. The group of EBV + diffuse large B-cell lymphomas includes a recently defined subtype known as diffuse large B-cell lymphoma of the elderly, in which immunological deterioration is additionally associated with the aging process. ${ }^{27-35}$ The polymorphous subtype of diffuse large B-cell lymphoma of the elderly, in particular, is additionally associated with a polymorphous background consisting of a broad range of B-cell maturation and mixture of reactive elements, including small lymphocytes, plasma cells and histiocytes, similar to that seen in acute EBV infection. These cases can also be associated with large areas of geographic necrosis and ReedSternberg-like cells. Thus, in an older and/or immunocompromised patient, the distinction between EBV + diffuse large B-cell lymphoma and acute EBV infection can be challenging. Of note, there have also been reports describing rare cases of EBV-positive diffuse large B-cell lymphoma 
Table 4 Immunoblast immunophenotype

\begin{tabular}{|c|c|c|c|c|c|c|c|c|}
\hline \multirow[t]{2}{*}{ Score } & \multicolumn{2}{|c|}{$0+($ absent $)$} & \multicolumn{2}{|c|}{$1+$} & \multicolumn{2}{|c|}{$2+$} & \multicolumn{2}{|c|}{$3+$} \\
\hline & No. & $\%$ & No. & $\%$ & No. & $\%$ & No. & $\%$ \\
\hline CD20 & 0 & 0 & 0 & 0 & 7 & 39 & 11 & 61 \\
\hline $\mathrm{EBER}^{\mathrm{a}, \mathrm{b}}$ & 0 & 0 & 0 & 0 & 15 & 83 & 3 & 17 \\
\hline MUM1/IRF4 & 0 & 0 & 0 & 0 & 8 & 44 & 10 & 56 \\
\hline OCT-2 & 0 & 0 & 0 & 0 & 9 & 56 & 7 & 44 \\
\hline BOB.1 & 0 & 0 & 0 & 0 & 10 & 63 & 6 & 38 \\
\hline CD30 & 0 & 0 & 1 & 8 & 10 & 77 & 2 & 15 \\
\hline CD15 & 11 & 100 & 0 & 0 & 0 & 0 & 0 & 0 \\
\hline BCL-2 & 8 & 47 & 3 & 18 & 6 & 35 & 0 & 0 \\
\hline CD3 & 12 & 67 & 6 & 33 & 0 & 0 & 0 & 0 \\
\hline BCL-6 & 16 & 88 & 2 & 12 & 0 & 0 & 0 & 0 \\
\hline CD10 & 18 & 100 & 0 & 0 & 0 & 0 & 0 & 0 \\
\hline
\end{tabular}

\begin{tabular}{|c|c|c|c|c|c|c|}
\hline & \multicolumn{2}{|c|}{ No staining } & \multicolumn{2}{|c|}{ Polyclonal } & \multicolumn{2}{|c|}{ Clonal } \\
\hline & No. & $\%$ & No. & $\%$ & No. & $\%$ \\
\hline$\kappa / \lambda \mathrm{IHC}$ & 3 & 19 & 13 & 72 & 0 & 0 \\
\hline
\end{tabular}

To assess the relative expression of particular antigens by immunoblasts, the positivity of the each immunostain was scored as follows: $0+$, absent staining in immunoblasts; $1+,<10 \%$ immunoblasts positive; $2+, 10-80 \%$ immunoblasts positive; $3+,>80 \%$ immunoblasts positive.

${ }^{\mathrm{a}}$ In-situ hybridization for EBER (Epstein-Barr virus-encoded RNA); all other markers assessed by immunohistochemistry.

${ }^{b}$ The overall percentage of cells that were positive for EBER ranged from 10 to $70 \%$ in the most strongly positive areas (mean: $35 \%$; median: $30 \%$ ).

occurring in younger, apparently immunocompetent patients. ${ }^{36}$ These cases are morphologically and immunophenotypically similar to cases observed in patients $>50$ years old, and seem to have a similarly poor prognosis. Thus, EBV-positive diffuse large B-cell lymphoma cannot be ruled out solely on the basis of age and apparent immunocompetence. In these rarer cases, the demonstration of polyclonal $\kappa$ and $\lambda$ immunoglobulin expression in EBV + immunoblasts may be additionally helpful in distinguishing acute EBV infection from EBV + diffuse large B-cell lymphoma. Heterophile/serological assays for acute EBV infection and molecular genetic studies (eg for clonality of the immunoglobulin genes) may also be important in making this distinction. However, it is important to note that PCR amplification of spurious or nonspecific clones in the setting of restricted but benign reactive populations of normal lymphocytes can sometimes lead to false positives. ${ }^{30,33,37}$

Classical Hodgkin lymphoma was considered or diagnosed by the submitting pathologist in four of the cases reviewed. Classical Hodgkin lymphoma accounts for $>90 \%$ of all Hodgkin lymphoma, and shows a bimodal age distribution, with the first peak in early adulthood (age 15-35 years) and second peak in those older than 55 years. ${ }^{38}$ Cervical lymph nodes are the most common site of involvement (75\% of cases). Notably, classical Hodgkin lymphoma occurs rarely in mucosa-associated lymphoid tissue, such as Waldeyer's ring. ${ }^{38-41}$ Both classical
Hodgkin lymphoma and infectious mononucleosis are characterized by a similar polymorphous background consisting of plasma cells, histiocytes and small lymphocytes, but eosinophils are rare in infectious mononucleosis and usually numerous in classical Hodgkin lymphoma. The presence of Reed-Sternberg-like cells in some cases of infectious mononucleosis is notorious for causing confusion with Hodgkin's disease. The Reed-Sternberg cell of classical Hodgkin lymphoma and the ReedSternberg-like cell of infectious mononucleosis are not only similar cytologically, but are also similar in their expression of the activation antigen CD30, EBV-encoded RNA transcripts (although not common in young adults with nodular sclerosing classical Hodgkin lymphoma) and their lack of

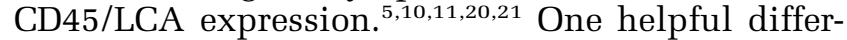
entiating feature is the expression of CD15 in ReedSternberg cells of classical Hodgkin lymphoma and lack of expression of CD15 in Reed-Sternberg-like cells of infectious mononucleosis. ${ }^{21}$ However, classical Hodgkin lymphoma can infrequently be negative for CD15, ${ }^{27,42-44}$ making this distinction more difficult. Moreover, Reed-Sternberg cells of classical Hodgkin lymphoma have the same non-germinal center immunophenotype that characterized the immunoblasts of the current infectious mononucleosis cases. Therefore, the retention of both OCT-2 and BOB.1 in the current series of infectious mononucleosis cases mimicking classical Hodgkin lymphoma may particularly be helpful in difficult 

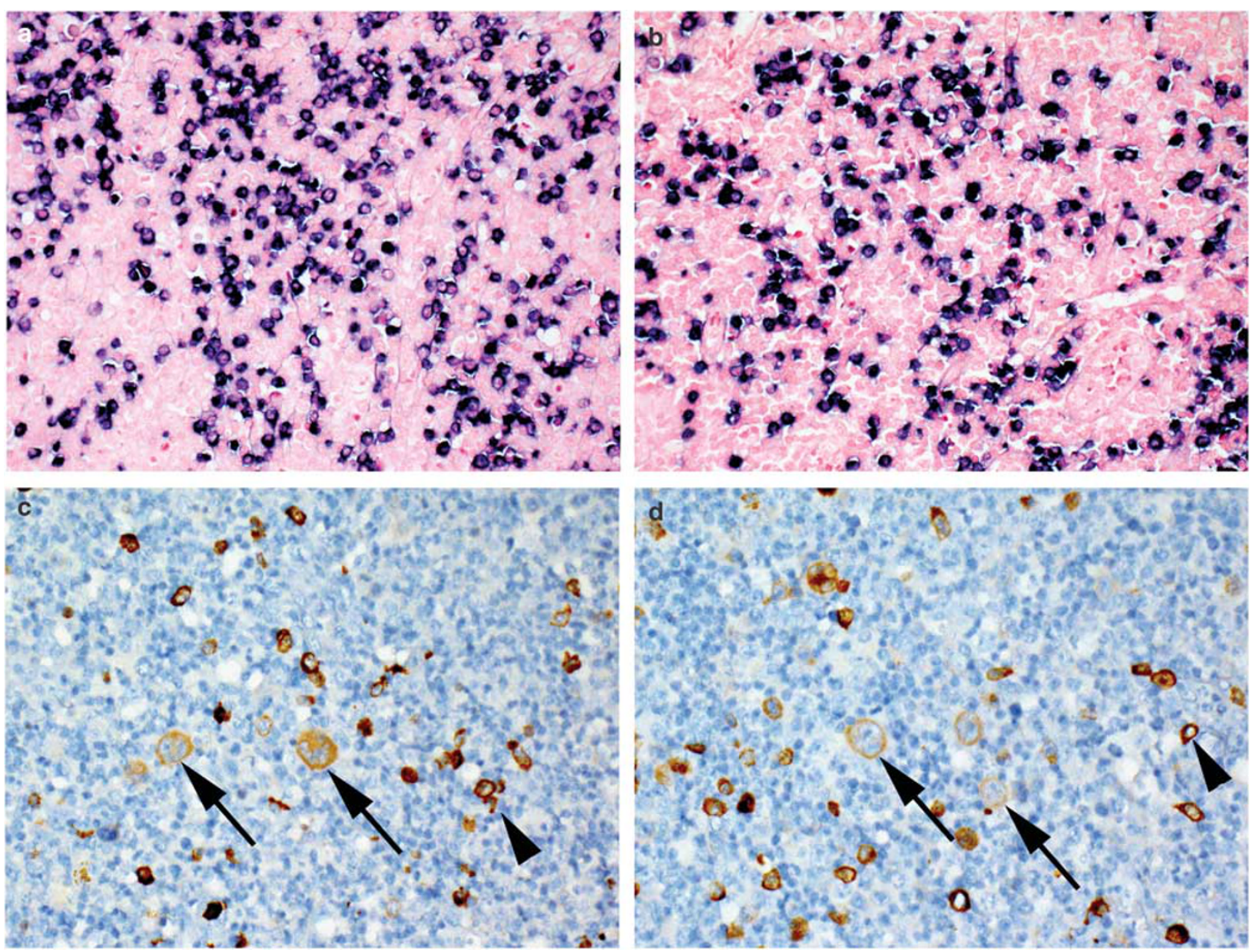

Figure 4 Immunoglobulin light-chain expression. In-situ hybridization for $\kappa$ and $\lambda$ immunoglobulin light chains revealed numerous polyclonal plasma cells within the interfollicular infiltrate $(\mathbf{a}, \mathbf{b})(\mathbf{a}: \kappa ; \mathbf{b}: \lambda)$. It was often difficult to definitively identify light-chain expression on immunoblasts with this assay. Immunohistochemical stains for $\kappa$ and $\lambda$ light chains revealed polyclonal light-chain expression on occasional immunoblasts (arrows), in addition to scattered polyclonal plasma cells (arrowheads) (c, d) (c: $\kappa$; d: $\lambda$ ).

cases, as one of these markers is usually lost in Reed-Sternberg cells of classical Hodgkin lymphoma. Of note, molecular genetic assays for B-cell clonality are not very useful in distinguishing infectious mononucleosis from classical Hodgkin lymphoma, as such assays usually fail to detect the rare neoplastic Reed-Sternberg cells in classical Hodgkin lymphoma (thus appearing falsely negative), as a result of the paucity of neoplastic cells in these lymphomas ${ }^{45,46}$

In summary, infectious mononucleosis should be considered in any immunoblastic proliferation occurring in cervical lymph nodes and Waldeyer's ring tissue. The distinction between infectious mononucleosis and lymphoma will often be made on morphological grounds; however, in difficult cases, an atypical lymphoid infiltrate with numerous MUM1/IRF4 +, CD10-, BCL-6- immunoblasts should raise the suspicion of infectious mononucleosis/acute EBV infection and warrants additional consideration before a diagnosis of lymphoma is made. Immunohistochemical stains for OCT-2/ BOB.1 and $\kappa / \lambda$ light chains may be additionally helpful in particularly difficult cases mimicking diffuse large B-cell lymphoma or classical Hodgkin lymphoma. This immunophenotypic profile is an important one to keep in mind to avoid a misdiagnosis of lymphoma in challenging cases.

\section{Disclosure/conflict of interest}

The authors declare no conflict of interest.

\section{References}

1 Luzuriaga K, Sullivan JL. Infectious mononucleosis. N Engl J Med 2010;362:1993-2000.

2 Heath Jr CW, Brodsky AL, Potolsky AI. Infectious mononucleosis in a general population. Am J Epidemiol 1972;95:46-52. 
3 Horwitz CA, Henle W, Henle G, et al Clinical and laboratory evaluation of infants and children with Epstein-Barr virus-induced infectious mononucleosis: report of 32 patients (aged 10-48 months). Blood 1981;57:933-938.

4 Abdel-Aziz M, El-Hoshy H, Rashed M, et al EpsteinBarr virus infection as a cause of cervical lymphadenopathy in children. Int J Pediatr Otorhinolaryngol 2011;75:564-567.

5 Abbondanzo SL, Sato N, Straus SE, Jaffe ES. Acute infectious mononucleosis. CD30 (Ki-1) antigen expression and histologic correlations. Am J Clin Pathol 1990;93:698-702.

6 Salvador AH, Harrison Jr EG, Kyle RA. Lymphadenopathy due to infectious mononucleosis: its confusion with malignant lymphoma. Cancer 1971;27:1029-1040.

7 Dorfman RF, Warnke R. Lymphadenopathy simulating the malignant lymphomas. Hum Pathol 1974;5:519-550.

8 Krishnan J, Danon AD, Frizzera G. Reactive lymphadenopathies and atypical lymphoproliferative disorders. Am J Clin Pathol 1993;99:385-396.

9 McMahon NJ, Gordon HW, Rosen RB. Reed-Sternberg cells in infectious mononucleosis. Am J Dis Child 1970;120:148-150.

10 Poppema S, van Imhoff G, Torensma R, Smit J. Lymphadenopathy morphologically consistent with Hodgkin's disease associated with Epstein-Barr virus infection. Am J Clin Pathol 1985;84:385-390.

11 Isaacson PG, Schmid C, Pan L, Wotherspoon AC, Wright DH. Epstein-Barr virus latent membrane protein expression by Hodgkin and Reed-Sternberglike cells in acute infectious mononucleosis. J Pathol 1992;167:267-271.

12 Irving JA, Cameron BR, Ludemann JP, Taylor G. Florid infectious mononucleosis: clinicopathological correlation in acute tonsillectomy. Int J Pediatr Otorhinolaryngol 2002;66:87-92.

13 Takimoto T, Tanaka S, Ishikawa S, Umeda R. Infectious mononucleosis in the nasopharynx with a histological picture of malignant lymphoma. Arch Otolaryngol Head Neck Surg 1988;245:348-350.

14 Otteman LA, Greipp PR, Ruiz-Arguelles GJ, et al Infectious mononucleosis mimicking a B cell immunoblastic lymphoma associated with an abnormality in regulatory T cells. Am J Med 1985;78:885-890.

15 Kojima M, Nakamura S, Sugihara S, Sakata N, Masawa N. Lymph node infarction associated with infectious mononucleosis: report of a case resembling lymph node infarction associated with malignant lymphoma. Int J Surg Pathol 2002;10:223-226.

16 Kojima M, Nakamura S, Shuimizu K, Itoh H, Masawa N. Marginal zone B cell lymphomas of Waldeyer's ring-a report of two tonsillectomy cases resembling histomorphological features of inflammatory lesions. Pathol Res Pract 2001;197:781-784.

17 Kojima M, Nakamura S, Itoh H, et al Lymph node lesion in infectious mononucleosis showing geographic necrosis containing cytologically atypically B-cells. A case report. Pathol Res Pract 2004;200:53-57.

18 Segal GH, Kjeldsberg CR, Smith GP, Perkins SL. CD30 antigen expression in florid immunoblastic proliferations. A clinicopathologic study of 14 cases. Am J Clin Pathol 1994;102:292-298.

19 Shin SS, Berry GJ, Weiss LM. Infectious mononucleosis. Diagnosis by in situ hybridization in two cases with atypical features. Am J Surg Pathol 1991;15: 625-631.
20 Childs CC, Parham DM, Berard CW. Infectious mononucleosis. The spectrum of morphologic changes simulating lymphoma in lymph nodes and tonsils. Am J Surg Pathol 1987;11:122-132.

21 Reynolds DJ, Banks PM, Gulley ML. New characterization of infectious mononucleosis and a phenotypic comparison with Hodgkin's disease. Am J Pathol 1995;146:379-388.

22 Axelrod P, Finestone AJ. Infectious mononucleosis in older adults. Am Fam Physician 1990;42:1599-1606.

23 The Non-Hodgkin Lymphoma Classification Project. A clinical evaluation of the International Lymphoma Study Group classification of non-Hodgkin's lymphoma. Blood 1997;89:3909-3918.

24 Chan A, Chan D. Diffuse large B-cell lymphoma. In: Jaffe ES, Vardiman, JW, Campo E, Arber DA (eds). Hematopathology, 1st edn. Elsevier Saunders: St Louis, MO, 2011, pp 349-381.

25 Yamauchi A, Ikeda J, Nakamichi I, et al Diffuse large B-cell lymphoma showing an interfollicular pattern of proliferation: a study of the Osaka Lymphoma Study Group. Histopathology 2008;52:731-737.

26 Stein H, Mason DY, Gerdes J, et al The expression of the Hodgkin's disease associated antigen Ki-1 in reactive and neoplastic lymphoid tissue: evidence that Reed-Sternberg cells and histiocytic malignancies are derived from activated lymphoid cells. Blood 1985;66:848-858.

27 Zukerberg LR, Collins AB, Ferry JA, Harris NL. Coexpression of CD15 and CD20 by Reed-Sternberg cells in Hodgkin's disease. Am J Pathol 1991;139:475-483.

28 Shimoyama Y, Asano N, Kojima M, et al Age-related EBV-associated B-cell lymphoproliferative disorders: diagnostic approach to a newly recognized clinicopathological entity. Pathol Int 2009;59:835-843.

29 Hofscheier A, Ponciano A, Bonzheim I, et al Geographic variation in the prevalence of Epstein-Barr virus-positive diffuse large B-cell lymphoma of the elderly: a comparative analysis of a Mexican and a German population. Mod Pathol 2011;24:1046-1054.

30 Dojcinov SD, Venkataraman G, Pittaluga S, et al Agerelated EBV-associated lymphoproliferative disorders in the Western population: a spectrum of reactive lymphoid hyperplasia and lymphoma. Blood 2011;117:4726-4735.

31 Wong HH, Wang J. Epstein-Barr virus positive diffuse large B-cell lymphoma of the elderly. Leuk Lymphoma 2009;50:335-340.

32 Gibson SE, Hsi ED. Epstein-Barr virus-positive B-cell lymphoma of the elderly at a United States tertiary medical center: an uncommon aggressive lymphoma with a nongerminal center B-cell phenotype. Hum Pathol 2009;40:653-661.

33 Kojima M, Nakamura N, Itoh $\mathrm{H}$, et al Epstein-Barr virus-related atypical lymphoproliferative disorders in Waldeyer's ring: a clinicopathological study of 9 cases. Pathobiology 2010;77:218-224.

34 Kojima M, Kashimura M, Itoh $\mathrm{H}$, et al Epstein-Barr virus-related reactive lymphoproliferative disorders in middle-aged or elderly patients presenting with atypical features. A clinicopathological study of six cases. Pathol Res Pract 2007;203:587-591.

35 Nakamichi N, Wada N, Kohara M, et al Polymorphous lymphoproliferative disorder: a clinicopathological analysis. Virchows Arch 2010;456:269-276.

36 Beltran BE, Morales D, Quinones P, et al EBV-positive diffuse large B-cell lymphoma in young immunocompetent individuals. Clin Lymphoma Myeloma Leuk 2011. 
37 Chan JK, Kwong YL. Common misdiagnoses in lymphomas and avoidance strategies. Lancet Oncol 2010; 11:579-588.

38 Stein HDG, Delsol G, Pileri SA, Weiss LM, Poppema S, Jaffe ES. Classical Hodgkin lymphoma. Introduction. In: Swerdlow SH, Campo E, Harris NL, Jaffe ES, Pileri SA, Stein H, Thiele J, Vardiman JW (eds). WHO Classification of Tumours of Haematopoietic and Lymphoid Tissues, 3rd edn. IARC: Lyon, France, 2008, pp 326-329.

39 Quinones-Avila Mdel P, Gonzalez-Longoria AA, Admirand JH, Medeiros LJ. Hodgkin lymphoma involving Waldeyer ring: a clinicopathologic study of 22 cases. Am J Clin Pathol 2005;123:651-656.

40 Kapadia SB, Roman LN, Kingma DW, Jaffe ES, Frizzera G. Hodgkin's disease of Waldeyer's ring. Clinical and histoimmunophenotypic findings and association with Epstein-Barr virus in 16 cases. Am J Surg Pathol 1995;19:1431-1439.
41 Moghe GM, Borges AM, Soman CS, Naresh KN. Hodgkin's disease involving Waldeyer's ring: a study of four cases. Leuk Lymphoma 2001;41:151-156.

42 Hall PA, D'Ardenne AJ. Value of CD15 immunostaining in diagnosing Hodgkin's disease: a review of published literature. J Clin Pathol 1987;40:1298-1304.

43 Nguyen DT, Diamond LW, Hansmann ML, Fischer R. Differential diagnosis of L26-positive, CD15-negative Hodgkin's disease and large B-cell lymphoma with a high content of reactive T-cells: a morphologic and immunohistochemical study. Hematopathol Mol Hematol 1996;10:135-150.

44 Petrella T, Michiels JF, Michiels R, et al CD 15 antigen in Hodgkin's disease. Pathol Res Pract 1989;185:886-890.

45 Weiss LM, Chang KL. Molecular biologic studies of Hodgkin's disease. Semin Diagn Pathol 1992;9:272-278.

46 Stein H, Hummel M. Cellular origin and clonality of classic Hodgkin's lymphoma: immunophenotypic and molecular studies. Semin Hematol 1999;36:233-241. 